\title{
Samme utdanning - ulik jobb? \\ Spesialiseringspreferanser hos kvinnelige og mannlige politistudenter
}

\author{
Af Silje Bringsrud Fekjaer ${ }^{I}$
}

\begin{abstract}
Equal representation of men and women in all types of police jobs is an official goal of the Norwegian Police. However, there are still marked differences in the gender balance of specialisations. This paper examines specialisation preferences among male and female police academy students at the beginning of their educations. Three explanations of gender-based differences in preferences are explored: ideas related to work-family balance; notions as to what constitutes "real" police work; and opinions on men and women's ability to perform different tasks. The dataset used covers all first-year police students in Norway in 2010 $(N=635)$. The results show marked gender differences in specialisation preferences: male students are more interested in operative careers, while female students express more interest in crime prevention and investigation. However, none of the suggested explanations is supported in the empirical data, which indicates a need for alternative explanations of early differences in job specialisation preferences."
\end{abstract}

\section{Introduksjon}

Et offisielt mål for politietaten er at begge kjønn skal være representert $\mathrm{i}$ alle typer stillinger, og på sikt at det skal være like mange kvinner som menn i alle typer stillinger og på alle nivåer i politietaten (Politidirektoratet, 2011: 12). Chan, Devery og Doran (2003: 276) hevder at når man aktivt har forsøkt å rekruttere kvinner inn i politiyrket, er det fordi man har ønsket å skape radikale endringer i måten politiarbeid blir utført på. Ut fra dette perspektivet er det viktig at kvinner er representert innenfor alle typer politiarbeid. Likevel er det klare forskjeller i kvinners representasjon i de forskjellige avdelingene i politiet. Mens kvinner er godt representert innenfor seksuallovbrudd, rytterkorpset og lokal etterforskning,

* Title in English: Same education, different job? Job specialisation preferences among male and female police students. 
er det få kvinner innenfor Hundepatruljen, motorsyklistene og uropatruljen, og ingen kvinner innenfor Beredskapstroppen (Finstad, 2000). ${ }^{2}$ Et interessant spørsmål er hvorvidt dette er et resultat av det de opplever i yrkeslivet, som for eksempel andres holdninger og vanskeligheter med å kombinere jobb og familieliv, eller om det skyldes at menn og kvinner har ulike preferanser i utgangspunktet.

Spørsmålet som undersøkes i denne artikkelen er for det første hvorvidt menn og kvinner allerede når de starter på utdanningen har ulike preferanser for hva de vil jobbe med i politiet. Videre testes tidligere foreslåtte forklaringer på kjønnsforskjeller i jobbspesialisering. Tre forklaringer trekkes fram: Betydningen av preferanser for balansen mellom arbeid og familieliv, oppfatninger om hva som er ordenlig politiarbeid og syn på forskjeller i menn og kvinners egnethet til ulike arbeidsoppgaver. Disse spørsmålene undersøkes med utgangspunkt i data fra en spørreundersøkelse som dekker alle studentene som startet ved Politihøgskolen i $2010(\mathrm{~N}=635)$.

Spørsmålet om hva som skaper kjønnsforskjeller i spesialiseringsønsker og når de oppstår er viktig hvis man ønsker å oppnå en jevnere kjønnsfordeling innenfor de ulike avdelingene i politiet. Resultater som tyder på at dette skyldes kvinners ønsker om mulighet til å kombinere jobb og familieliv, indikerer et behov for å få til en mer familievennlig arbeidsorganisering. Resultater som tyder på at forskjellene skyldes ulikheter i interesser kan gi grunnlag for å satse på å motivere kvinnene for utradisjonelle valg. Dersom forskjellene er til stede allerede ved studiestart, vil eventuelle endringer av arbeidsforhold og holdninger i etaten ha mer begrenset betydning enn dersom forskjellene oppstår først etter at de har fătt erfaring fra yrkeslivet.

Hensiktsmessigheten av et politisk mål om jevn representasjon av kvinner kan diskuteres, kanskje spesielt hvis analysene viser at forskjellene i spesialiseringspreferanser er tilstede allerede før de starter i jobben og ser ut til å skyldes ulike interesser. Ønsket om å få inn kvinner i norsk politi var opprinnelig begrunnet med at kvinner ville utføre tjenesten annerledes og var best egnet til enkelte typer politiarbeid (Finstad, 2000: 237). Ut fra et slikt syn er kan det være ønskelig å få inn kvinner som ønsker seg andre arbeidsoppgaver enn menn. En kan imidlertid uansett finne argumenter for Politidirektoratets mål om kjønnsutjevning innenfor ulike spesialiseringer. Støtte for synet om at kvinners representasjon utgjør en forskjell finner vi hos Lagestad (2011), som viser at kvinner utfører ordenstjeneste annerledes enn menn. Spesielt ser de ut til å være mer dialogorienterte enn menn, noe som ofte, men ikke alltid, vil være en fordel. At kvinner er representert innenfor ulike spesialiteter vil også være viktig for å nå det offisielle målet om 
flere kvinner i lederstillinger, siden tidligere studier kan tyde på at mangel på variert erfaring generelt, og erfaring fra patruljering spesielt, kan hindre kvinners ledermuligheter i politiet (Österlind \& Haake, 2010).

\section{Forklaringer på kjønnssegregering i arbeidsmarkedet}

Gjerberg (2002) tar utgangspunkt i skillet mellom strukturorienterte forklaringer og individorienterte forklaringer for å forstå kjønnsforskjeller i spesialisering. Innenfor de strukturorienterte forklaringene er fokus på muligheter og begrensninger i strukturen. Spesielt viktig er arbeidsbetingelser og mulig diskriminering. Arbeidsbetingelser kan føre til at kvinner velger bort spesialiteter som innebærer forventninger om å jobbe mye, uregelmessig arbeidstid og lite muligheter for deltid. For kvinner vil dette begrense valget av spesialitet i den grad de fremdeles har mest ansvar på hjemmebane. Liv Finstad (2000: 240-241) drøfter kvinners større ansvar på hjemmebane som en av flere mulige forklaringer på kjønnsforskjeller i lokalisering innenfor politiet, fordi kvinner har større problemer enn menn med å kombinere skiftarbeid og familieliv.

Diskriminering vil være avgjørende hvis kvinner ikke făr tilgang til uformelle nettverk som regulerer tilgangen til posisjoner innenfor enkelte spesialiteter (Gjerberg, 2002). En annen mulighet er at det eksisterer forestillinger om at kjønn er avgjørende for om man er egnet til visse oppgaver. Liv Finstad (2000: 240241) har beskrevet hvordan holdninger i etaten kan være en av flere mulige forklaringer på kjønnsforskjeller i lokalisering. Blant ledelsen i etaten kan det fremdeles eksistere konservative oppfatninger om hva menn og kvinner egner seg best til. Dette må ses i sammenheng med tidligere tiders begrunnelser for å ha kvinner i politiet, da kvinner skulle rekrutteres fordi de var spesielt godt egnet til enkelte oppgaver. Kvinners medfølende natur gjorde dem egnet til avhør i sedelighetssaker, kriminalitetsforebygging, å håndtere saker med kvinner og ungdom og å beskytte kvinners sikkerhet (Appier, 1998: 3; Finstad, 2000: 237). Denne type oppfatninger er ikke uttalt på ledernivå i dag. Andre diskusjoner er fremdeles aktuelle, som hvorvidt kvinner er egnet til spesielle operative enheter som Beredskapstroppen. Et viktig spørsmål i denne sammenheng er hvorvidt kvinner og menn som starter på politiutdanningen selv oppfatter at kvinner og menn er ulikt egnet til forskjellige typer politiarbeid.

Fokus innenfor de individorienterte forklaringene er på individuelle kjønnsrelaterte preferanser og egenskaper, som påvirker valg og slik skaper kjønnssegregering. Årsaken til forskjellene i preferanser og egenskaper kan være kjønnsspesifikk sosialisering og/eller rasjonelle valg. Kjønnsspesifikk sosialisering innebærer at kjønnene sosialiseres ulikt og derfor vil ha ulike interesser og ulik grad 
av egnethet. I et politiperspektiv har Finstad (2000) drøftet kjønnsbestemt selvseleksjon som en mulig årsak til kjønnsforskjeller i spesialitet. Hun beskriver kvinnene som mindre interessert $\mathrm{i}$ enkelte typer politiarbeid. Det kan skyldes at kvinner og menn har ulike oppfatninger om hva som er meningsfullt eller »ordentlig « politiarbeid. Finstad kobler unge menn til en mer reaktiv politilogikk, hvor en god dag på jobben innebærer »en fange, en biljakt, en blåtur« (Finstad, 2000: 240), mens kvinnene beskrives som mer fokusert på de proaktive (forebyggende) sidene ved politiarbeidet.

Forskjeller i preferanser kan også skyldes rasjonelle valg. Gjerberg beskriver hvordan ønske om å prioritere familie kan gjøre det mindre rasjonelt å investere i en karriere innenfor enkelte spesialiteter. Omsorgsfratrekk betegner det man taper i yrkeslivet på grunn av omsorgsansvar, og kan være sterkere innenfor enkelte spesialiteter og yrker (Gjerberg, 2002: 76; Hansen, 1995). Innen politiet kan omsorgsfratrekket være større innenfor spesialiteter som krever skiftarbeid og operativ godkjenning. Tilsvarende har Hakim (2002) hevdet at preferanser er avgjørende for hvilken type jobb man velger. Ifølge Hakim er preferanser lite avgjørende for hvilket yrke man velger, som i dette tilfelle vil bety at det ikke stopper jentene fra å bli politi. Mange kvinner vil imidlertid ha ønske om å prioritere familieliv framfor karriere, og derfor velge de jobbene innenfor politiet som lar seg kombinere med omsorgsansvar. I desegregerte yrker med jevn kjønnsfordeling, som politiet, vil kvinner velge de mest familievennlige jobbene, mens mennene vil velge karriere-løpet (Hakim, 2002: 454). Hakims poeng er at dette ikke skyldes diskriminering, men ulike preferanser. Disse preferansene vil være stabile og til stede fra et tidlig tidspunkt. Hakim hevder at valget av jobb kan forklares med mange kvinners preferanser for å bruke mye tid med familien og for å ha mulighet til å jobbe deltid, og derfor må forstås som et rasjonelt valg.

Som vi har sett er det mange ulike forklaringer på kjønnssegregering i yrkeslivet. Intensjonen i denne artikkelen er å beskrive hvorvidt kjønnssegregeringen er tydelig allerede ved oppstart på utdanningen, og å vurdere tre av forklaringene på kjønnsforskjeller som har blitt drøftet her: betydningen av preferanser for familieliv og deltidsarbeid (Hakim, 2002), ulike oppfatninger om hva som er meningsfullt og ekte politiarbeid (Finstad, 2000) og/eller egne oppfatninger av hva menn og kvinner er best egnet til (Finstad, 2000). Disse tre forklaringene vil alle kunne være gyldige for å forklare preferanseulikheter som er tilstede allerede ved studiestart, og har blitt trukket fram i innflytelsesrike teoretiske studier og/eller studier som omhandler politiet som yrkesgruppe spesielt. 


\section{Hva vet vi om kjønnssegregering i politiet?}

Kvinner og menns tendens til å jobbe innenfor ulike spesialiteter i politiet er dokumentert $\mathrm{i}$ både norske og internasjonale studier. I Norge har Finstad (2000) vist at kvinner er underrepresentert innenfor enkelte spesialiteter (bl.a. Hundetjenesten og uropatruljen), og forholdsmessig overrepresentert innenfor andre (f.eks. rytterkorpset og lokal etterforskning). I Australia har Chan et. al. (2003: 292) funnet en viss støtte for at kvinner og menn settes til ulike oppgaver i politiet. Kvinner făr oftere ansvar for barn og kvinnelige ofre, og særlig sedelighetssaker. Andre funn fra Australia og New Zealand viser at kvinner er underrepresentert innenfor enheter som jobber med statlig sikkerhet/terrorisme og spesialisert kriminalitet, mens de er overrepresentert innenfor etterforskning og administrasjon (Prenzler, Fleming, \& King, 2010). Kvinners underrepresentasjon i amerikanske SWAT-teams, som tilsvarer den norske beredskapstroppen, drøftes i Dodge, Valcore og Klinger (2010), mens Holdaway og Parker (1998) viser engelske politikvinners underrepresentasjon i trafikkavsnittet og etterforskningsenheten CID.

Vår kunnskap om hvorfor en slik kjønnssegregering oppstår er begrenset. Ingen systematiske studier har hatt som eksplisitt formål å avdekke årsaker til kjønnssegregering i politiet. Flere forskere har imidlertid berørt emnet i arbeidet med andre temaer. Lagestad (2011: 131) lanserer en mulig forklaring om at det i politiet har eksistert en oppfatning om at kvinner er bedre egnet til å løse politioppgaver som krever verbale framfor fysiske egenskaper, som etterforskning og forebygging framfor ordenstjeneste. Lagestad trekker frem dette som en mulig årsak, men vektlegger samtidig at situasjoner som krever fysisk styrke i praksis utgjør en svært liten andel av ordenstjenesten. Her kan man imidlertid innvende at selv om de utgjør en liten andel av oppgavene, er det svært viktig de gangene fysisk styrke kommer til anvendelse, både for politiets egen sikkerhet og for opprettholdelsen av lov og orden. En forestilling om ordenspatrulje som fysisk krevende vil være reell i sine konsekvenser, uansett om den har rot i virkeligheten, og kunne føre til at kvinner velger bort arbeidet som ordenspoliti. Forskjeller i fysisk styrke har også blitt trukket fram som en viktig årsak til at kvinner er underrepresentert i den amerikanske beredskapstroppen (Dodge, et al., 2010), men her fremheves også andre årsaker, som en mannsdominert kultur og at kvinner i større grad enn menn må bevise at de virkelig er egnet for oppgaven. At kvinner i større grad enn menn opplever at de blir begrenset i forhold til hvilke oppgaver de blir satt til å gjøre i politiet er et funn i Holdaway og Parkers (1998) engelske studie. Tilsvarende beskriver Rabe-Hemp (2008) hvordan kvinnelige amerikanske politioffiserer opplever at de blir presset av ledelsen til å ta seg av »kvinneoppgavene«, som arbeid med barn, kvinnelige ofre og administrative oppgaver, selv om 
flere av kvinnene i Rabe-Hemps materiale har nektet å tilpasse seg dette og valgt typiske mannlige spesialiteter.

Fokus i denne artikkelen er på betydningen av preferanser for kjønnssegregering i politiyrket. På dette området er det få tidligere studier. Et unntak er nevnte Lagestad (2011: 139) som bygger på kvalitative data når han hevder at mannlige politistudenter i større grad enn kvinnene foretrekker actionpreget politiarbeid, og at kvinnene finner de kommunikasjonsmessige delene av yrket mer givende. En årsak kan være at kvinner generelt, og fysisk lave kvinner spesielt, opplever at de i liten grad blir gitt tillit til å løse fysisk krevende oppdrag (Lagestad, 2011: 150). Lagestads kvantitative materiale viser at mannlige politistudenter opplever menn som bedre egnet til å løse situasjoner som krever fysisk styrke, mens ca. halvparten opplever kvinner som bedre egnet til å løse situasjoner som krever verbale ferdigheter (Lagestad, 2011: 142). Også Granér (2004) har ut fra kvalitative data funnet at politikvinners verbale ferdigheter vektlegges. Men bildet er mer nyansert: Både de mannlige og de kvinnelige politistudentene er i liten grad tiltrukket av innearbeid og papirarbeid, og ønsker i stedet å være ute blant publikum der det skjer noe (Granér, 2004: 242). Davidsen og Reiersen (2010) har vist at et ønske om videreutvikling på andre felter er en viktig grunn til at kvinner i politiet forlater ordenstjenesten, men dette ser ut til å gjelde i like stor grad for menn som slutter på orden. Internasjonale studier gir heller ikke et entydig svar på hvorvidt det er kjønnsforskjeller i preferanser for ulike typer politiarbeid. Mens Wimshurst (1995) ikke finner forskjeller mellom kvinnelige og mannlige politirekrutter på New Zealand når det gjelder hva de ønsker å jobbe med, rapporterer Holdaway og Parker (1998) at kvinnene er mindre interessert i trafikk og fotpatruljering, mens de er mer interessert i arbeid med ungdom, familiekonflikter og avhør.

Kjønnsforskjeller i preferanser for ulike typer arbeid i politiet har ikke vært studert i større utvalg i Norge. En interessant parallell finner vi imidlertid i Gjerbergs (2002) studie av leger, en profesjon som i likhet med politiet er preget av sterk økning i kvinneandelen, høye inntakskrav og dedikerte studenter. Gjerberg finner store kjønnsforskjeller i spesialiseringsmønster, og forskjellene blir større utover i yrkesløpet. Dette kan tyde på at eventuelle forskjeller som denne studien finner blant politistudenter kan forsterkes utover i karrieren. Blant legene er kvinnene overrepresentert innenfor spesialiseringer rettet mot barn, kvinner og eldre, mens mennene fremdeles dominerer innenfor blant annet indremedisin og kirurgi. Skifte av spesialitet ser ut til å kunne ha sammenheng med utestengning av kvinner innen enkelte fagfelt. Dette kan være aktuelt også i enkelte mannsdominerte politienheter, som uro og beredskapstroppen. En slik eventuell utestengning er imidlertid ikke dokumentert. 
Gjerberg trekker fram arbeidsforhold og tilpasningen mellom jobb og familie som viktige forklaringer på ulikheter i spesialisering. Kvinners bruk av deltid, antall barn og tidspunkt for barnefødsler varierer mellom fagfeltene, noe som tyder på at de strukturelle betingelsene innenfor fagfeltet er viktige for kvinners valg. Tilsvarende er det nærliggende å anta at enkelte fagfelt innenfor politiet vil være enklere å kombinere med familieliv på grunn av familievennlige ordninger og holdninger. For eksempel vil det å velge etterforskning fremfor arbeid på en ordensavdeling gi mulighet for deltid, regulerte arbeidstider uten skift og å beholde arbeidsoppgavene under graviditet. Gjerbergs (2002) viser at kvinner ofte faller fra enkelte spesialiseringsløp når de făr barn. Dette samsvarer med Davidsen og Reiersen (2010) som har vist at problemer med å kombinere turnus med omsorg for barn er en viktig årsak til at kvinner i politiet slutter på ordensavdelinger. Særlig nattevakter ser ut til å være problematisk.

Den tidligere forskningen viser at det er klare forskjeller i menn og kvinners arbeidsområder innenfor politiet, både i Norge og internasjonalt. Forskningen på årsaker til disse forskjellene er imidlertid begrenset, og gir ikke grunnlag for entydige konklusjoner. I denne artikkelen er formålet å se nærmere på omfanget av tidlige kjønnsforskjeller i spesialiseringsønsker, og å undersøke gyldigheten av foreslåtte forklaringer på ulikheter i preferanser.

\section{Data}

Datasettet som benyttes er samlet inn som en del av forskningsprosjektet Recruitment, Education and Careers in the Police: A European Longitudinal Study. Dette prosjektet vil etter hvert omfatte Norge, Sverige, Danmark, Finland, Island, Belgia, Skotland, Estonia, Ungarn, Slovenia, Tyskland (Hessen, Brandenburg, Thüringen, Hamburg) og Spania (Catalonia). Politistudentene i disse landene skal følges opp med jevnlige spørreskjemaundersøkelser, fra de starter i utdanningen og fram til de har vært i arbeidslivet i seks år. Forskningsdesignet er basert på STUDdataundersøkelsen som er utviklet av Senter for profesjonsstudier (SPS, 2011). Spørsmålene omhandler bakgrunn, verdier, oppfatninger av politiutdanningen og forventninger og holdninger til politiarbeid. Til sammen vil dette prosjektet gi en unik mulighet for å studere politifolk i et longitudinelt og komparativt perspektiv.

Datasettet som benyttes i denne artikkelen er fra første fase av studien, som dekker alle førsteårs politistudenter i Norge i $2010(N=635)$. Studentene fylte ut skjemaene på høgskolen. Svarprosenten er derfor uvanlig høy, $84.5 \%$. Studentene ble spurt i løpet av sine første uker på studiet, noe som kan antas å prege svarene: de vil i liten grad ha gått gjennom sosialiseringen som skjer i løpet av studiet når de svarer. 
Den avhengige variabelen, studentenes framtidsorientering, er basert på spørsmålet Hvis du prøver å forestille deg livet om ti år, hvor sannsynlig er det at utsagnene nedenfor vil passe for deg? Først vises en oversikt over de ulike arbeidsoppgavene: som ordenspoliti, med etterforskning, med forebygging, med etterretning og analyse, med administrasjon og ledelse, $i$ en operativ spesialenhet (for eksempel Utrykningsenheten) og ikke lenger i politiet. I de videre analysene fokuseres det spesielt på spørsmålene om studentenes planer om en operativ karriere, dvs. ordenspoliti og operativ spesialenhet. Teori, tidligere forskning og debatten innad i politiet gir grunn til å anta at det vil være spesielt interessant å kartlegge hvorfor kvinnene eventuelt velger bort operative karrierer (se Davidsen \& Reiersen, 2010).

For å måle graden av arbeid/fritidsorientering tas det utgangspunkt i spørsmålet Hvor viktig synes du følgende forhold er når man skal vurdere en jobb? Indeksen er konstruert på basis av følgende fire underspørsmål: En jobb med fleksibel arbeidstid, en jobb med mulighet til deltidsarbeid, en jobb som gir mye fritid og en jobb som gir tid til overs til å drive med andre ting. Skalaen går fra 0-4, der 4 indikerer at man er orientert mot fritid, mens 0 indikerer at man er orientert mot jobb (Cronbachs alpha 0,68). Studentenes syn på om mannlig og kvinnelig politi egner seg til ulike oppgaver er målt ut fra en indeks basert på tre spørsmål: Mannlige polititjenestemenn er bedre egnet enn kvinnelige når det gjelder å løse situasjoner der det forekommer vold, kvinnelige polititjenestemenn er bedre enn mannlige til a vise omsorg for kvinner og barn og kvinnelige polititjenestemenn er bedre på å kommunisere enn mannlige. Skalaen går fra 0-4, der 4 indikerer at man mener at kjønnene er ulikt egnet, dvs. at menn er bedre egnet til visse oppgaver og kvinner til andre, mens 0 indikerer at man er uenig i påstandene om at et kjønn er bedre egnet (Cronbachs alpha 0,72). Spørsmålet om studentenes syn på hva som er ordentlig politiarbeid lyder I hvilken grad anser du at oppgavene nedenfor er eksempler på ordentlig politiarbeid? og er målt på en skala fra 0 til 4 . Studentene er i stor grad enige om at de fleste oppgavene som er nevnt er å anse som ordentlig politiarbeid (for eksempel etterforskning, patruljering og forebygging). Indeksen er derfor konstruert på basis av de tre områdene hvor det er en viss uenighet blant studentene om hvorvidt de er å anse som eksempler på ordentlig politiarbeid (standardavvik over 0,8): trafikkontroll, rapportskriving og å bistå andre offentlige instanser som f.eks. sosialtjenesten. Skalaen går fra 0-4, der 4 indikerer at man mener at disse oppgavene i meget stor grad er eksempler på ordentlig politiarbeid, mens 0 indikerer at man mener at de ikke i det hele tatt er eksempler på ordentlig politiarbeid (Cronbachs alpha 0,75). Operasjonaliseringen av de tre sentrale forklaringsvariablene problematiseres nærmere i diskusjonen av resultatene. 
De øvrige uavhengige variablene inkluderer kjønn ( $0=\mathrm{kvinne}, 1=$ mann), alder $(0=20-22, \quad 1=23-25,3=26-29,4=30+)$, tidligere utdanning ( $0=$ videregående, $1=$ høyskole/universitet), barn ( $0=$ ingen, $1=1$ eller flere), foreldres utdanning ( $0=$ begge foreldre grunnskole/videregående, $1=$ minst en av foreldrene høyskole/universitet) og hvorvidt en av foreldrene har politiutdanning ( $0=$ nei, $1=\mathrm{ja}$ ). Studentenes fordeling på de uavhengige variablene er vist i tabellen under.

Tabell 1: Deskriptiv statistikk. Norske politistudenter 2010.

\begin{tabular}{lrcr}
\hline & \multicolumn{1}{c}{ Alle } & Kvinnelige studenter & Mannlige studenter \\
\hline Arbeid/fritid orientering & $2,2(0,6)$ & $2,2(0,6)$ & $2,2(0,6)$ \\
Ulik egnethet & $1,8(1,0)$ & $\mathbf{1 , 6}(1,0)$ & $\mathbf{1 , 8}(0,9)$ \\
Ordentlig politiarbeid & $3,2(0,7)$ & $\mathbf{3 , 4}(0,7)$ & $\mathbf{3 , 2}(0,7)$ \\
Alder & $23,1(2,8)$ & $22,8(2,7)$ & $23,3(2,9)$ \\
\hline & & Prosent & $4 \%$ \\
Har barn & $38 \%$ & $5 \%$ & $\mathbf{3 1} \%$ \\
Tidl. høyere utdanning & $74 \%$ & $\mathbf{5 0} \%$ & $74 \%$ \\
Foreldre høy utdanning & $9 \%$ & $74 \%$ & $10 \%$ \\
Mor/far politi & $635(100 \%)$ & $7 \%$ & $409(64 \%)$ \\
\hline N & & $226(36 \%)$ & \\
\hline
\end{tabular}

Uthevet=signifikant forskjellig på $5 \%$ nivå.

Tabell 1 viser at mannlige og kvinnelige politistudenter på mange vis er relativt like. Det er ikke signifikante forskjeller når det gjelder hvor gamle de er, om de har barn fra tidligere, om de har foreldre med høy utdanning og om de har en mor eller far som er politi. Spesielt interessant er det at det ikke er kjønnsforskjeller på indexen som måler arbeid/fritids orientering. Det innebærer at både mannlige og kvinnelige politistudenter ved studiestart ser ut til å være noe mer orientert mot jobb enn mot å prioritere fritid.

På enkelte områder er det imidlertid signifikante forskjeller mellom mannlige og kvinnelige politistudenter. Særlig stor forskjell er det i andelen som har tatt høyere utdanning før de begynner på Politihøgskolen: Mens ca halvparten av kvinnene har utdanning fra før, gjelder dette under en tredjedel av mennene. De mest interessante forskjellene i denne sammenheng er likevel forskjellene i synet 
på egnethet og oppfatningene av hva som er ordentlig politiarbeid. Her ser vi at mennene i noe større grad mener at det er forskjell på hva slags politiarbeid kvinner og menn er best på, men forskjellen er ikke veldig stor (1,6 vs 1,8). Mennene mener i noe mindre grad at trafikkontroll, rapportskriving og å bistå andre offentlige instanser er eksempler på ordentlig politiarbeid, men også her er det kun 0,2 som skiller kjønnene på en skala fra 0 til 4 . Et gjennomsnitt på over 3 forteller oss at begge kjønn i relativt stor grad mener at også dette er ordentlig politiarbeid.

\section{Resultater}

Det første spørsmålet som skal undersøkes her er hvorvidt kvinnelige og mannlige politistudenter har ulike preferanser for hva de vil jobbe med. Figur 1 viser kvinnelige og mannlige politistudenters oppfatninger av hva det er sannsynlig at de vil jobbe med om ti år.

Figur 1. Hvor sannsynlig er det at du om 10 år arbeider med ...

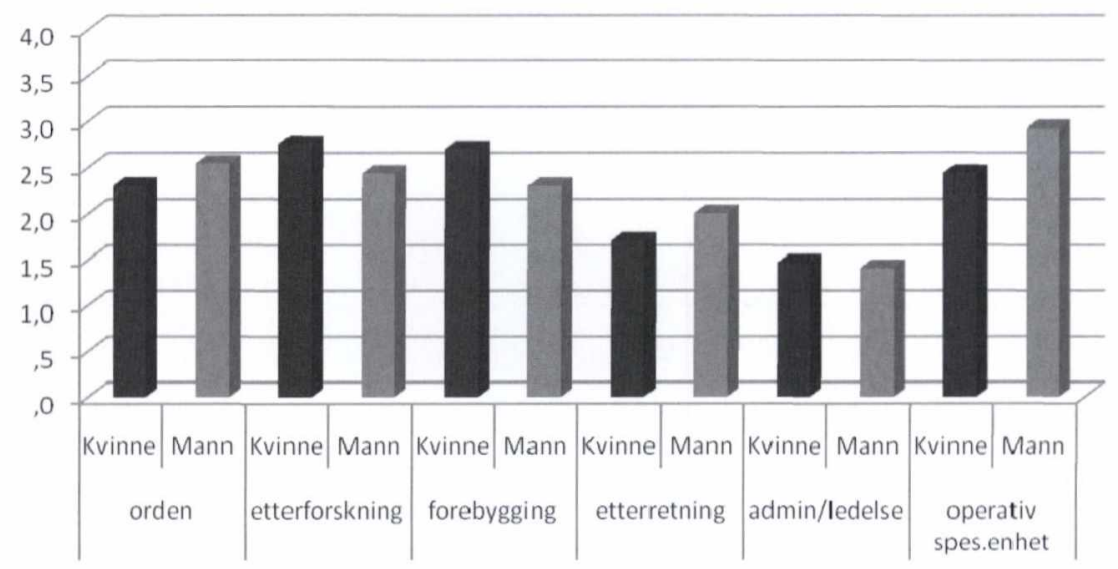

Figuren viser at det er klare kjønnsforskjeller i oppfatningene av hvor man kommer til å jobbe om ti år. T-tester viser at alle forskjellene er signifikante, med unntak av feltet administrasjon og ledelse. Vi ser at menn finner det mer sannsynlig at de kommer til å jobbe som ordenspoliti, med etterretning og særlig i en operativ spesialenhet. Kvinnene regner det som mer sannsynlig at de om 10 år jobber med etterforskning og forebygging. Når det gjelder sannsynligheten for å jobbe med administrasjon og ledelse er det lite forskjeller mellom kjønnene. ${ }^{3}$ 
Det neste spørsmålet som skal besvares er hvorvidt vi finner dekning for tidligere teorier om hva som kan forklare kjønnsforskjeller i spesialiseringsønsker. Her er fokuset på to områder hvor kvinners deltakelse har vært spesielt diskutert: Arbeid på ordensavdeling (tabell 2) og arbeid i en operativ spesialenhet (tabell 3). Skyldes kjønnsforskjellene i spesialiseringsønsker at menn og kvinner har ulike preferanser for balansen mellom arbeid og fritid, ideer om kjønnsforskjeller i hva man er best egnet til og/eller at menn og kvinner har ulike ideer om hva som er ordentlig politiarbeid? For å undersøke dette er det utført lineære regresjoner som viser om de opprinnelige kjønnsforskjellene (modell \#1) endres når vi innfører kontroll for de tre forklaringsvariablene preferanser for arbeid/fritid, oppfatning av kjønnsforskjeller i egnethet og oppfatning av hva som er ordentlig politiarbeid (modell \#2). Tilslutt innføres kontroll for bakgrunnsvariabler, som også kan antas å påvirke preferansene for å jobbe på orden og i en operativ spesialenhet (modell \#3). ${ }^{4}$

Tabell 2. Preferanser for å jobbe på orden avhengig av kjønn, arbeid/fritid preferanser, ideer om kjønnsforskjeller $i$ egnethet og oppfatning av hva som er ordentlig politiarbeid. b (std.feil).

\begin{tabular}{|c|c|c|c|}
\hline & Modell \#1 & Modell \#2 & Modell \#3 \\
\hline Kjønn (kvinne= 0 ) & $.25(0.08)$ & $.29(0.09)$ & $.29(0.09)$ \\
\hline Arbeid/fritid preferanser & & $.01(0.07)$ & $-.03(0.07)$ \\
\hline Kjønnsforskjeller i egnethet & & $-.01(0.04)$ & $-.03(0.04)$ \\
\hline Oppfatning ordentlig politiarbeid & & $.13(0.06)$ & $.12(0.06)$ \\
\hline Alder: $23-25$ år (20-22 år =0) & & & $.02(0.10)$ \\
\hline Alder: 26-29 år & & & $-.30(0.15)$ \\
\hline Alder: $30+$ år & & & $-.23(0.21)$ \\
\hline Barn (ingen =0) & & & $-.13(0.22)$ \\
\hline Tidligere utdanning (lav=0) & & & $-.09(0.09)$ \\
\hline Foreldres utdanning (lav $=0$ ) & & & $-.22(0.10)$ \\
\hline Mor/far politi (nei=0) & & & $.54(0.15)$ \\
\hline Konstant & $2.30(0.07)$ & $1.86(0.26)$ & $2.21(0.30)$ \\
\hline Justert $r^{2}$ & 0.01 & 0.02 & 0.05 \\
\hline $\mathrm{N}$ & 631 & 614 & 581 \\
\hline
\end{tabular}

Uthevet $=$ signifikant på $5 \%$ nivå. 
Resultatene i tabell 2 gir liten støtte for alle de tre testede teoriene for å forklare kjønnsforskjeller i spesialiseringsønsker. Kjønnsforskjellene er bemerkelsesverdig stabile i modell 1 og 2 . Forskjellene viser ingen tegn til å svekkes, da heller en svak tendens til å styrkes. Det betyr at når vi sammenligner mannlige og kvinnelige politistudenter som er like med hensyn til preferanser for arbeid/fritid, ideer om kjønnsforskjeller i egnethet og oppfatninger om hva som er ordenlig politiarbeid, er det fremdeles klare forskjeller mellom mannlige og kvinnelige studenter: mannlige studenter plasserer seg 0,3 høyere på en skala fra 0-4 der 4 er at det er svært sannsynlig at man jobber på orden. At kjønnsforskjellene er konstante når vi sammenligner de som er like med hensyn til alle de tre forklaringsvariablene, tyder på at dette ikke er årsaken til kjønnsforskjellene i preferanser for å jobbe på orden. Vi ser også at verken preferanser for arbeid/fritids balansen eller ideer om forskjeller i hva menn og kvinner er best egnet til har sammenheng med planer om å jobbe på orden. Når det gjelder syn på hva som er ordentlig politiarbeid er det en svak tendens til at de som i størst grad mener at trafikkontroll, rapportskriving og å bistå andre offentlige instanser er eksempler på ordentlig politiarbeid også er mest positive til å jobbe på orden, men forskjellen er beskjeden. Med hensyn til bakgrunnsvariablene viser modell 3 at de yngste, de som har lavt utdannede foreldre og de som har foreldre som er politi er mest innstilt på å fortsette på orden (men forskjellene er moderate). Tidligere utdanning og det å ha barn ser ut til å ha liten betydning for planer om å fortsette på orden. Justert $\mathrm{r}^{2}$ bekrefter inntrykket av at verken forklaringsvariablene eller bakgrunnsvariablene er spesielt sentrale for å forstå variasjonen i preferanser: Til sammen forklares kun 5 $\%$ av variasjonen i preferanser for å jobbe på orden (modell 3). 
Tabell 3. Preferanser for å jobbe i en operativ spesialenhet avhengig av kjønn, arbeid/fritid preferanser, ideer om kjønnsforskjeller $i$ egnethet og oppfatning av hva som er ordentlig politiarbeid. b (std.feil).

\begin{tabular}{|c|c|c|c|}
\hline & Modell \#1 & Modell \#2 & Modell \#3 \\
\hline Kjønn (kvinne=0) & $.49(0.08)$ & $.52(0.08)$ & $.52(0.09)$ \\
\hline Arbeid/fritid preferanser & & $.13(0.06)$ & $.11(0.07)$ \\
\hline Kjønnsforskjeller i egnethet & & $.03(0.04)$ & $.03(0.04)$ \\
\hline Oppfatning ordentlig politiarbeid & & $.07(0.06)$ & $.06(0.06)$ \\
\hline Alder: $23-25$ år (20-22 år=0) & & & $.05(0.10)$ \\
\hline Alder: 26-29 år & & & $-.16(0.14)$ \\
\hline Alder: $30+$ år & & & $.22(0.21)$ \\
\hline Barn (ingen $=0$ ) & & & $-.22(0.22)$ \\
\hline Tidligere utdanning (lav $=0$ ) & & & $-.12(0.09)$ \\
\hline Foreldres utdanning $(\mathrm{lav}=0)$ & & & $-.11(0.10)$ \\
\hline Mor/far politi (nei=0) & & & $.03(0.15)$ \\
\hline Konstant & $2.44(0.07)$ & $1.85(0.27)$ & $2.06(0.29)$ \\
\hline Justert $r^{2}$ & 0.06 & 0.07 & 0.07 \\
\hline $\mathrm{N}$ & 632 & 615 & 582 \\
\hline
\end{tabular}

Uthevet $=$ signifikant på $5 \%$ nivå.

I tabell 3 ser vi at de tre teoriene om årsaker til kjønnsspesialisering har liten forklaringskraft også når det gjelder hva som påvirker planer om å jobbe i en operativ spesialenhet. Mannlige studenter scorer ca 0,5 høyere på en skala fra 0 til 4 når vi spør hvor sannsynlig det er at de om 10 år jobber i en operativ spesialenhet, og denne kjønnsforskjellen reduseres ikke når vi i modell 2 innfører kontroll for arbeid/fritids preferanser, syn på kjønnsforskjeller i egnethet og oppfatninger om hva som er ordentlig politiarbeid. At kjønnsforskjellene består når vi sammenligner de som er like med hensyn til disse forklaringsvariablene, tyder på at dette ikke er årsaken til kjønnsforskjellene i planene om å jobbe i en operativ spesialenhet. Syn på kjønnsforskjeller i egnethet og oppfatninger om hva som er ordentlig politiarbeid har da også liten sammenheng med hvorvidt man ønsker å jobbe i en operativ spesialenhet. Vi finner en viss tendens til at de som er innstilt på å prioritere fritid noe oftere har planer om å jobbe i en operativ spesialenhet, noe som 
vanskelig kan antas å begrunnes ut fra en ide om at arbeidspresset er mindre i disse enhetene. Snarere er det vel trolig å tenke seg at en viss type politistudenter både er mer fritidsorientert og har en større interesse for å jobbe i en operativ spesialenhet, uten at det ene vil være årsak til det andre. Når det gjelder bakgrunnsvariablene i modell 3, finner vi at disse har liten sammenheng med planene om å jobbe i en operativ spesialenhet. Kjønn ser ut til å være den eneste av faktorene i tabellen som har en klar sammenheng med tendensen til å planlegge en karriere $\mathrm{i}$ en operativ spesialenhet. Også $\mathrm{i}$ denne tabellen bekrefter justert $r^{2}$ inntrykket av at forklaringsvariablene og bakgrunnsvariablene ikke er spesielt sentrale for å forstå variasjonen i preferanser for å jobbe i en operativ spesialenhet. Kun $7 \%$ av variasjonen forklares i modell 3, hvor alle de uavhengige variablene er inkludert.

\section{Hvorfor finner vi liten støtte for tidligere forklaringer av kjønnsforskjeller i spesialisering?}

Kvinnelige og mannlige politistudenter har ulike preferanser for hva de vil jobbe med allerede når de starter i politiutdanningen. Dette tyder på at individuelle preferanser er en viktig del av forklaringen på hvorfor de jobber med ulike typer politiarbeid. Når det gjelder spørsmålet om hva de ulike preferansene skyldes, tyder resultatene i denne artikkelen på at de årsakene som har blitt foreslått i tidligere teoretiske arbeider, forskning fra andre yrker og kvalitativ politiforskning, ikke er særlig nyttige når det gjelder å forklare tidlige kjønnsforskjeller i preferanser for spesialisering i politiet, i hvert fall ikke når det gjelder å arbeide på orden og i en operativ spesialenhet. ${ }^{5}$ Verken preferanser for balansen mellom arbeid og fritid, oppfatning om ulikheter i egnethet for enkelte typer politiarbeid eller oppfatninger om hva som er ordentlig politiarbeid ser ut til å kunne forklare forskjellene mellom kvinnelige og mannlige politistudenter.

Hvorfor finner vi liten støtte for de foreslåtte forklaringene? Et alternativ er at dette skyldes metodologiske begrensninger, spesielt svakheter ved validiteten til de kvantitative målene som her er brukt for å operasjonalisere forklaringene fra tidligere teori og forskning. Indeksen som brukes for å måle hvorvidt kvinner og menn er ulikt egnet for forskjellige oppgaver inkluderer kun hvorvidt menn er bedre egnet til å løse voldelige situasjoner, og hvorvidt kvinner er bedre på å kommunisere og vise omsorg. Her er det mulig å tenke seg at de kvinnelige studentene av andre grunner tenker at de er mindre egnet for arbeid på orden og $\mathrm{i}$ operativ spesialenhet. Spesielt kan kvinner oppleve å ha mindre autoritet i ordenstjenesten fordi de er fysisk mindre (se Lagestad, 2011), og oppleve seg som lite kvalifisert for spesialenheter som Beredskapstroppen på grunn av fysiske be- 
grensninger (Dodge, et al., 2010). Samtidig har tidligere studier vist at selvopplevde fysiske begrensninger i liten grad har betydning når kvinner velger bort jobber på ordensavdeling (Davidsen \& Reiersen, 2010).

I tillegg til egne oppfatninger av hva kvinner og menn er best egnet til, vil andres oppfatninger av hva kvinner og menn bør arbeide med kunne påvirke studentenes valg av spesialitet. Tidligere studier har vist at politistudenter i stor grad har gjennomgått en presosialisering før de starter studiet, hvor de har klare oppfatninger om politirollen allerede når de begynner (Chan, et al., 2003: 62; Lauritz, 2009). Dette kan også innebære oppfatninger av hva menn og kvinner er best egnet til innenfor politiet. Siden vi måler kjønnsforskjeller i preferanser for spesialitet når studentene akkurat har begynt på utdanningen, er det imidlertid grunn til å tro at andre politifolks oppfatninger av hva kvinner og menn er egnet til i begrenset grad har påvirket deres planer om spesialisering: ideene om hva andre mener om egnethet trolig være relativt svakt utviklet på dette punktet. For å forklare kjønnsforskjeller i preferanser som er tilstede allerede ved studiestart, virker det mest rimelig å spørre etter studentenes egne oppfatninger om egnethet, som målet av oppfatninger om egnethet i denne artikkelen er basert på. Andres oppfatninger av egnethet vil trolig bli viktigere for spesialiseringspreferanser som oppstår senere i karrieren.

Indeksen som måler preferanser for arbeid/fritids balanse inkluderer preferanser for deltidsarbeid, fleksibel arbeidstid, mye fritid og tid til overs. Dette vil dekke mye av det Hakim (2002) beskriver som sentralt for kvinner som ikke er karriereorienterte. En innvending her vil være at siden kvinnene i denne undersøkelsen i all hovedsak er unge og barnløse, vil de ennå ikke ha innsett betydningen av en jobb som lar seg kombinere med familieliv. Hakims teori postulerer imidlertid at disse preferansene er stabile over livsløpet, og derfor allerede vil være til stede også hos unge og barnløse kvinner. Uansett er målet i denne artikkelen å forklare de kjønnsforskjellene i spesialiseringspreferanser som kan observeres allerede ved studiestart. Når også unge barnløse kvinner i større grad velger vekk orden og operative spesialenheter, kan dette ikke skyldes deres negative erfaringer med å kombinere jobb og familieliv. Dersom de velger det vekk ut fra en forventning om at dette vil bli vanskelig å kombinere i fremtiden, ville man anta at de også allerede nå ville ønske seg en jobb med mer familievennlig arbeidstid. Blant de unge kvinnene finner vi altså ikke igjen Davidsen og Reiersens (2010) funn om betydningen av balanse i arbeid/familieliv for erfarne politikvinner som velger bort jobber på ordensavdelinger. Davidsen og Reisersens funn gir imidlertid grunn til å anta at familiehensyn trolig vil bli viktigere hvis vi følger disse kvin- 
nene over tid og ser på hva som har betydning for deres spesialiseringsvalg på senere tidspunkt.

Oppfatninger om hva som er ordentlig politiarbeid er trolig det vanskeligste å måle. Indeksen som er benyttet her er basert på i hvilken grad man oppfatter trafikkontroll, rapportskriving og å bistå andre offentlige instanser som eksempler på ordentlig politiarbeid. Selv om det er en viss spredning, ser vi at studentene også her i stor grad krysser av at de synes dette er ordentlig politiarbeid. $\AA$ gi uttrykk for at noe ikke er ordentlig politiarbeid vil trolig bli mer fremtredende når studentene har vært ute i praksis, de første ukene vil mange være positivt innstilt til alle sider ved yrket. Kanskje er også slike holdninger vanskelig å måle fordi det ikke er helt legitimt å tilkjennegi at man tar avstand fra enkelte deler av yrket. Det er også mulig at dette spørsmålet burde vært formulert slik at det i større grad fanger opp de actionfylte delene av yrket som Liv Finstad fokuserer på når hun fremlegger denne forklaringen på kjønnsforskjeller (Finstad, 2000: 240). Samtidig viser tabell $1 \mathrm{i}$ denne artikkelen at det er relativt små forskjeller mellom de kvinnelige og de mannlige studentene når det gjelder synet på hva som er ordentlig politiarbeid, mens det allerede er klare forskjeller i spesialiseringspreferanser. Mye tyder derfor på at heller ikke forskjeller i hva man oppfatter som ordentlig politiarbeid er en tilfredsstillende forklaring på kjønnsforskjeller i spesialiseringspreferanser.

Begrepet ordentlig politiarbeid har vært trukket fram i flere sentrale arbeider innenfor den nordiske politiforskningen (se f.eks. Finstad, 2000; Granér, 2004). Det kan imidlertid være et vanskelig begrep å operasjonalisere, både kvantitativt og kvalitativt. Kanskje kan vi ikke spørre direkte om hva man oppfatter som ordentlig politiarbeid, men bør i stedet forsøke å måle det mer indirekte, for eksempel ved å lage et batteri av spørsmål som til sammen kan indikere noe om synet på hva som er og ikke er ordentlig politiarbeid. Så lenge begrepet står sentralt innenfor nordisk politiforskning, bør man tilstrebe å utvikle mål som gjør at vi også kan finne det igjen i empirien.

Som vi har sett er det grunn til å drøfte hvorvidt operasjonaliseringene i denne studien virkelig vil dekke inn alle aspekter av de forklaringene som er beskrevet i teori og tidligere forskning. Samtidig virker det rimelig å anta at målene som er brukt her burde fanget inn i hvert fall en del aspekter ved de faktorene som tidligere er antatt å forklare kjønnsforskjeller. Når resultatene svært entydig viser at de foreslåtte forklaringene ikke har noen forklaringskraft, gir det grunn til å stille spørsmål ved anvendbarheten av de tidligere foreslåtte forklaringene. Årsaker til at disse forklaringene ikke ser ut til å være spesielt fruktbare inkluderer at de ikke er utviklet for å forklare forskjeller som oppstår før studentene starter i yrkeslivet, 
at forklaringene ikke er overførbare til norske forhold, at forklaringer basert på andre yrkesgrupper er mindre gyldige innenfor politiet og at resultatene fra kvalitative studier ikke gjenfinnes i et større og mer representativt kvantitativt materiale.

Forklaringene som testes i denne artikkelen, er i utgangspunktet utviklet for å forstå forskjeller som er tilstede etter at karrieren er påbegynt. Hakim (2002) hevder imidlertid at systematiske kjønnsforskjeller i preferanser er stabile. Når vi finner at preferanser for balansen arbeid/fritid ikke er viktig for de unge studentene og ikke kan forklare kjønnsforskjellene, gir dette derfor ikke støtte for Hakims teori. Finstads forklaringer er i større grad utviklet for å forklare forskjeller som man finner etter noen år i arbeidslivet (Finstad, 2000). En fullstendig forklaring av slike forskjeller bør imidlertid også ta høyde for at forskjellene kan være tilstede allerede ved studiestart.

Med hensyn til internasjonal overførbarhet er det spesielt grunn til å stille spørsmål ved hvorvidt Hakims teori om kvinners stabile og ulike preferanser vil være gyldig i en skandinavisk kontekst (se Halrynjo, 2010 for en kritikk av Hakims teori generelt, og overførbarheten til norske forhold spesielt). Det er også grunn til å stille spørsmålstegn ved hvorvidt Hakims teori er anvendbar på kvinner i politiet, en sterkt selektert gruppe som i utgangspunktet er høyt motivert for arbeidet sitt. Tidligere funn tyder på at Hakims teori ikke er velegnet for å beskrive politikvinners karrieremessige motivasjon (Fekjær \& Halrynjo, 2012).

Når resultatene i denne artikkelen ikke viser støtte for Finstads (2000) foreslåtte forklaringer om ideer om kjønnsulikheter i egnethet og oppfatninger av hva som er meningsfullt politiarbeid, kan en årsak være at dagens unge politistudenter skiller seg fra de hun møtte tidlig på 1990-tallet. Mye har skjedd både med utdanningen på Politihøgskolen og med kvinners stilling i politiet i løpet av de snart 20 årene som har gått siden Finstad startet sitt prosjekt i 1993. Samtidig kan et kvantitativt materiale som dekker hele kullet med politistudenter gi andre svar enn det et størrelsesmessig og geografisk mer begrenset kvalitativt materiale vil gi. Likevel skal vi også være bevisste på den allerede nevnte muligheten for at Finstad kvalitativt har fanget opp meningsforskjeller blant kvinner og menn som de kvantitative målene på et spørreskjema ikke er i stand til å fange opp.

\section{Veien videre}

Resultatene i denne studien viser klare forskjeller i kvinnelige og mannlige politistudenters planer om spesialisering. Allerede ved studiestart er mennene mer innstilt på karrierer innenfor blant annet orden og operative spesialenheter, mens kvinnene er mer innstilt på å fortsette med etterforskning og forebygging. I analy- 
sen testes tre ulike forklaringer på kjønnsforskjeller i spesialisering. Resultatene viser at verken forskjeller i preferanser for balansen mellom arbeid og fritid, ulike oppfatninger om hva som er ordentlig politiarbeid eller ideer om kjønnsforskjeller i egnethet kan forklare de ulikhetene vi finner. Disse forklaringene kan fremdeles være viktige for å forstå kjønnsforskjeller i spesialiseringspreferanser som oppstår utover i karrieren, men ser altså ikke ut til å være årsak til de forskjellene som er tilstede allerede ved studiestart.

Selv om en kan diskutere validiteten til enkelte av målene i studien, gir de entydige resultatene uansett grunn til å åpne for alternative forklaringer av tidligere kjønnsforskjeller i spesialiseringsønsker blant politistudenter. Hvilke alternative forklaringer virker rimelige? Kvinners omsorgsansvar i hjemmet og arbeidsbetingelser som gjør det vanskelig å kombinere enkelte yrkesløp i politiet med familieliv har tidligere blitt trukket fram som en viktig forklaring (Davidsen \& Reiersen, 2010; Finstad, 2000: 240-241). Også diskriminering i arbeidslivet og andres oppfatninger av hva menn og kvinner egner seg til kan skape ulike karrierepreferanser hos menn og kvinner i politiet. Dette kan være viktige forklaringer på hvorfor kvinner som er i gang med yrkeskarrieren og har etablert seg med familie, velger vekk enkelte spesialiseringer. Samtidig virker det lite sannsynlig at disse forklaringene skal være dekkende for å forstå de kjønnsforskjellene som er tilstede allerede når studentene starter utdanningen. Politistudentene i denne undersøkelsen har liten eller ingen erfaring fra politietaten, og er fremdeles i all hovedsak unge og barnløse. Det er derfor grunn til å anta at eventuelle diskriminerende/stereotypiske oppfatninger i etaten og belastningen ved omsorgsansvar i liten grad preger deres valg. I praksis betyr det at arbeid for å påvirke holdninger i etaten og fremme familievennlige arbeidsbetingelser muligens kan bidra til å minske underrepresentasjonen av kvinner i enkelte enheter, men trolig aldri føre til en fullstendig jevn kjønnsmessig representasjon, siden kvinners preferanser for andre arbeidsoppgaver ser ut til å være til stede også før de i særlig grad er påvirket av andres holdninger og eget omsorgsansvar.

En mulig forklaring på kjønnsforskjellene som er tilstede allerede ved studiestart er ulike preferanser som en følge av kjønnsspesifikk sosialisering. Gjerberg (2002) beskriver hvordan ulik sosialisering av gutter og jenter kan føre til at de utvikler ulike interesser og ulik grad av egnethet. Bjerrum Nielsen (1998) har beskrevet slående forskjeller i sosialiseringen av gutter og jenter, også i de yngre generasjonene. I vår sammenheng kan det innebære at kvinnene som starter på Politihøgskolen allerede i utgangspunktet har andre interesser og oppfatninger av egne evner enn mennene. Det er for eksempel mulig at kvinnene i større grad ser det som urealistisk at de om ti år jobber i en operativ spesialenhet, fordi de er klar 
over at det er svært vanskelig å bli tatt opp ved disse enhetene. Kvinnene kan også være mer beskjedne og derfor ikke ønske å gi inntrykk av at de tror de selv er egnet til en såpass krevende karriere. At kvinner i mindre grad enn menn oppfatter seg selv som kompetente er funnet også i studier av politifolk (Wexler \& Quinn, 1985). ${ }^{6}$

En annen mulighet er at mennene i større grad enn kvinnene fremdeles er påvirket av gamle forestillinger om politiarbeid. Storvik (2002) har beskrevet hvordan idealene i arbeidslivet er i endring, og at såkalte feminine egenskaper har blitt mer sentrale. Hvis dette er tilfelle i politiet, er det heller ikke overraskende at kvinner i større grad orienterer seg mot de formene for politiarbeid som har blitt mer vektlagt de senere årene, og da spesielt forebygging og annet kunnskapsbasert politiarbeid (Gundhus, 2009).

En tredje mulighet er at kvinnene i noe mindre grad er interessert i de mer risikofylte og spenningsfylte delene av arbeidet (Lagestad, 2011: 139). ${ }^{7}$ Her skal en imidlertid huske på at kvinnene som søker Politihøgskolen er en meget selektert gruppe som trolig skiller seg sterkere fra andre kvinner, relativt til mennene. Videre forskning er nødvendig for å fastslå hvilken betydning kjønnsspesifikk sosialisering har for ulikheter i spesialisering. Ut fra denne studien kan vi konkludere med at det finnes klare kjønnsforskjeller i spesialiseringspreferanser i politiet allerede i et tidlig stadium, og at mye tyder på at vi må tenke nytt når det gjelder hvordan vi skal forklare disse forskjellene.

\section{Noter}

1. Silje Bringsrud Fekjær er førsteamanuensis i kvantitativ metode ved Politihøgskolens forskningsavdeling. Fekjær disputerte i 2007 ved Institutt for sosiologi og samfunnsgeografi, Universitetet i Oslo. Hennes forskningsinteresser omfatter blant annet rekruttering til politiet, politiets utdanning og arbeidshverdag samt statistiske metoder

2. Disse tallene vil trolig være noe endret, men dessverre finnes ingen samlet oversikt over dette per 2011. Det er imidlertid all grunn til å anta at kjønnsfordelingen innen ulike spesialiteter er skjev også i dag. Vi vet blant annet at det fremdeles aldri har vært kvinner i Beredskapstroppen (BT, 2011), og at det i 2005 kun var $5 \%$ kvinner i Utrykningsenheten (UEH) (PHS, 2011).

3. Se Fekjær og Halrynjo (2012) for en nærmere analyse av forskjeller i menn og kvinners lederambisjoner og prioritering av karrieremuligheter i politiet.

4. Det har også blitt testet analyser hvor forklaringsvariablene innføres trinnvis i separate modeller. Siden dette ikke medfører endringer i resultatene, vises kun tre modeller for å forenkle fremstillingen. I tillegg er det testet analyser hvor bakgrunnsvariablene innføres $\mathrm{i}$ modell $\# 1$, men siden heller ikke dette medfører noen vesentlige endringer i resultatene, innføres bakgrunnsvariablene først i de siste modellene for å lette tabellens lesbarhet. Tes- 
ter av analyser med samspillsledd viser at forklaringsvariablene har samme effekt for kvinner og menn.

5. Ytterligere analyser (ikke vist her) tyder på at disse forklaringene har begrenset betydning også for å forklare kjønnsulikheter i preferanser for de andre spesialiseringene.

6. Denne studien er imidlertid relativt gammel, skjemmet av en lav svarprosent og ikke nødvendigvis overførbar til norske forhold.

7. Foreløpige analyser (ikke vist her) bekrefter at også blant politistudentene er kvinnene noe mindre risikoorienterte enn guttene. Her bør en imidlertid foreta nye analyser med andre mål for risikosøking, da spørsmålet Bare fordi det er spennende og risikofylt, liker jeg av og til å gjøre ting som er farlig eller forbudt blir lite valid anvendt på politistudenter, som nok skiller mellom det som er farlig og det som er forbudt. På spørsmålet om hvorvidt det er viktig med en jobb som gir mulighet for spenning og action er det ingen signifikante forskjeller mellom kjønnene, noe som tyder på at dette ikke er en fullgod forklaring på kjønnsforskjeller i spesialiseringspreferanser.

\section{Referanser}

Appier, J. (1998). Policing women. The sexual politics of law enforcement and the LAPD. Philadelphia: Temple University Press.

BT. (2011). Dette er beredskapstroppen. Hentet 29.09., 2011, fra http://mobil.bt.no/nyheter/ innenriks/Dette-er-beredskapstroppen-2545138.html

Chan, J.B.L., Devery, C., \& Doran, S. (2003). Fair cop: learning the art of policing. Toronto: University of Toronto Press.

Davidsen, G.I., \& Reiersen, L. (2010). Hvorfor slutter kvinner $i$ ordenstjenesten i politiet? Masteroppgave. Politihøgskolen, Oslo.

Dodge, M., Valcore, L., \& Klinger, D.A. (2010). Maintaining separate spheres in policing: women on SWAT teams. Women \& Criminal Justice, 20(3), 218-238.

Fekjær, S.B., \& Halrynjo, S. (2012). Promotion aspirations among male and female police students International Journal of Police Science and Management, 14(1), 71-82.

Finstad, L. (2000). Politiblikket. Oslo: Pax.

Gjerberg, E. (2002). Kvinner i norsk medisin - mot full integrering? En studie av kjønndifferensiering i legers spesialitetsvalg. Oslo: Universitetet i Oslo/Arbeidsforskningsinstituttet.

Granér, R. (2004). Patrullerande polisers yrkeskultur. Lund Dissertations in Social Work 18. Lund: Socialhøgskolan, Lunds universitet.

Gundhus, H.I. (2009). For sikkerhets skyld - IKT, yrkeskulturer og kunnskapsarbeid i politiet. Oslo: Unipub.

Hakim, C. (2002). Lifestyle preferences as determinants of women's differentiated labor market careers. Work and Occupations, $29(1), 428-459$.

Halrynjo, S. (2010). Mødre og fedre i møte med karrierelogikkens spilleregler: hva skjer med høyt utdannede kvinners og menns karriere- og familietilpasning når de får barn? og hvordan kan tilpasningene foklares? Oslo: Institutt for sosiologi og samfunnsgeografi, Det samfunnsvitenskapelige fakultet/Unipub.

Hansen, M.N. (1995). Kjønnssegregering i det norske arbeidsmarkedet. Kan forskjeller i lønnsstruktur bidra til at kvinner og menn velger ulike yrker? Tidsskrift for samfunnsforskning, 36(2), 147-177. 
Holdaway, S., \& Parker, S.K. (1998). Policing women police. Uniform patrol, promotion and representation in the CID. British Journal of Criminology, 38(1), 40-60.

Lagestad, P. (2011). »Fysisk styrke eller bare prat«. Om kjønn, fysisk trening og ordenstjeneste $i$ politiet. Oslo: Doktorgrad ved Norges idrettshøgskole.

Lauritz, L.E. (2009). Spirande polisidentiteter - en studie av polisstudenters och nya polisers professionella identitet. Doktorsavhandling 2009. Umeå: Handelshøgskolan, Umeå universitet.

Nielsen, H.B. (1998). Små piger, søde piger, stille piger - om pigeliv og pigesocialisering. I K. Klette (Red.), Klasseromsforskning på norsk. Oslo: Ad notam Gyldendal.

PHS. (2011). Karrieremoglegheiter i politiet: operativ tjeneste. Hentet 05.10., 2011, fra http://www.phs.no/no/Karriere/Muligheter-i-politiet/Operativ-tjeneste/

Politidirektoratet. (2011). Plan for mangfoldsarbeidet i politi- og lensamennsetaten 2008-2013. Hentet 01.07., 2011, fra https://www.politi.no/vedlegg/rapport/Vedlegg_562.pdf

Prenzler, T., Fleming, J., \& King, A.L. (2010). Gender equity in Australian and New Zealand policing: a five-year review. International Journal of Police Science and Management, 12(4), 584-595.

Rabe-Hemp, C. (2008). Survival in an »all boys club«: policewomen and their fight for acceptance. Policing: An International Journal of Police Strategies and Management, 31(2), 251-270.

SPS. (2011). StudData - database for studier av rekruttering og kvalifisering til profesjonell yrkesutøvig. Hentet 03.10., 2011, fra http://www.hio.no/content/view/full/9162

Storvik, A.E. (2002). Maskulinitet og makt i utakt. I A.L. Ellingsæter \& J. Solheim (Red.), Den usynlige hånd? Kjønnsmakt og moderne arbeidsliv (s. 266-290). Oslo: Gyldendal akademisk.

Wexler, J.G., \& Quinn, V. (1985). Considerations in the training and development of women sergeants. Journal of Police Science and Administration, 13(2), 98-105.

Wimshurst, K. (1995). Anticipating the future: the early experiences and career expectations of women police recruits in post-Fitzgerald Queensland. Australian and New Zealand Journal of Criminology, 28(3), 278-297.

Österlind, M., \& Haake, U. (2010). The leadership discourse amongst female police leaders in Sweden. Advancing Women in Leadership Journal, 30(16). 